This is a pre-copy-editing, author-produced PDF of an article accepted for publication in Journal of Environmental Law following peer review. The definitive publisher-authenticated version Journal of Environmental Law (2007) Vol 19 No. 2, 227-246 is available online at: http://www.jel.oxfordjournals.org

\title{
PUBLIC POLICY AND THE DIGITAL GEOSPATIAL REPRESENTATION OF DESIGNATED LAND USE IN THE UK - PART II
}

\author{
Dr. STEPHEN SAXBY*
}

\begin{abstract}
In the post-war period, since the National Parks and Access to the Countryside Act 1949, successive UK governments have developed policies for the management of land use and marine conservation. This process accelerated at the Millennium with the passage of the Countryside and Rights of Way Act. Now, in 2006, the present Government has promoted the passage through Parliament of both the Commons Act and the Natural Environment and Rural Communities Act, and a new Marine Bill is not far behind. If successful such measures will further expand and develop the means to secure and protect designated land and the marine environment. An important issue here is how the Government plans to embrace digital geospatial techniques in the development of policy towards the conservation and management of such geographic space. A more specific issue concerns the prospects for conversion from paper to digital form of maps of open country, commons, town and village greens and public rights of way that carry conclusive or definitive status in court. This paper, presented in two parts, looks at current developments and recent research on these topics and assesses the feasibility of such transition. In doing so it takes account of eGovernment and transformational policies and the mechanism to promote digitisation of records set out in the Electronic Communications Act 2000. It concludes that the adoption of geospatial techniques as a tool for developing policy towards designated land and the marine environment has much to commend it, as does development of a national geographic information strategy for government as a whole. Whilst the paper focuses on developments in UK law, the policy issues raised are applicable to all governments and jurisdictions.
\end{abstract}

\section{Definitive and conclusive map records in electronic formats}

The development of OSMM, structured to DNF standards, ${ }^{135}$ offering a digital base map for integration of geospatial information, has provided an important foundation for future expansion of online definitive mapping in the UK. Creation of a sound mapping infrastructure is,

\footnotetext{
${ }^{*}$ Reader in Information Technology Law, School of Law, Southampton University, PhD, Solicitor. Address: Faculty of Law, Arts and Social Sciences, The University, Highfield, Southampton, SO17 1BJ. (023 8059 3404; email: s.j.saxby@soton.ac.uk). My thanks to Tim Jewell, Barrister at the Department for the Environment, Food and Rural Affairs, Keith Murray, Head of Geographic Information Strategy, Ordnance Survey and Phil Watts, Corporate Strategist (Long Term Strategy), Ordnance Survey and to Chris Hill of the GeoData Institute, Southampton University, for their helpful advice and analysis in relation to an earlier draft of this paper. It should be noted, however, that the opinions expressed in this paper are entirely the author's and do not necessarily represent those of the reviewers or the organisations they represent.

${ }^{135}$ See note 77 ante.

(C) Stephen Saxby 2006 All rights reserved 
nevertheless, only the first step in building the relationship between national mapping activity and exploitation of digital technology. As time passes the transition from paper to digital formats in public administration is going to impose increasing demands for digital map data sets to be adopted. In some cases there will be pressure to move from indicative to definitive map status in which the digital information presented is conclusive as evidence of what it contains. Not all mapping services, however, will require this further step to be taken. This is because OS, in any case, is committed to continual improvement of its base map products as shown, for example, by its current investment in the PAI programme ${ }^{136}$ which is designed to tidy up any discrepancies in geographic positioning within its base map operations. For many applications, the high standard of indicative accuracy to be found within OSMM should suffice, as opposed to the more exacting standards and process requirements that must accompany any transition to definitive status.

OSMM is now available to all government departments, agencies and local authorities in digital format. It can now be applied to an increasing range of public sector activity involving spatial policy elements. Illustrations of the adoption of maps in digital form in the discharge of statutory obligations and as a tool for policy development and planning are readily available, although neither a common nor comprehensive approach across the public sector to the transition from paper to electronic map formats appears to have been formulated. For example, whereas Forestry Commissioners may draw up maps in electronic form as part of a national register of forest reproductive material, ${ }^{137}$ and in Northern Ireland, maps in electronic form may be used for traffic management, ${ }^{138}$ the designation of Nitrate Vulnerable Zones applicable only to England are to be depicted on digital maps held on two CD-ROMs deposited in the DEFRA library. ${ }^{139}$ Whilst there has been a significant increase in the adoption of electronic communication as an acceptable means of facilitating transactional services with the citizen and securing public consultation in policy matters, ${ }^{140}$ there does not appear to be any evidence of coordination in policy towards digital map conversion within either the Government's better regulation or transformational agendas. If there was, this might set the Government down the path towards efficiency gains and improvements in these areas and in public access to information that is presently confined to that held on paper maps and statements. The result is a prescription for uncertainty and possible frustration among officials, interest groups and policymakers until the direction of future policy becomes clearer. ${ }^{141}$ It is also likely to present problems, particularly at borders, if devolved assemblies move at different speeds with projects for digital conversion to definitive status.

With regard to land use there are circumstances when legislation will require the maintenance of a definitive map and statement of the boundaries of that land. These records must visually depict, as far as possible, the legally valid representation of the exact geospatial location of the rights in question. Part IV of NPACA 1949, for example, established such arrangements for PROWs. The initial scheme, within that Act, was replaced by more comprehensive arrangements set out in WCA $1981^{142}$ and by secondary legislation. This included the requirement for periodic review

\footnotetext{
136 See note 81 ante

137 The Forest Reproductive Material (Great Britain) Regulations 2002 (S.I. 2002 No. 3026).

138 The Traffic Management (Northern Ireland) Order 2005 (S.I. 2005 No.1964 (N.I.14).

139 The Nitrate Vulnerable Zones (Additional Designations) (England) (No. 2) Regulations 2002 (S.I. 2002 No. 2614).

${ }^{140}$ This is evident from a search of statutory instruments which clearly shows this trend. See: www.opsi.gov.uk/stat.htm.

${ }^{141}$ Private law interests should also be considered here in the context of land registration for example.

${ }^{142}$ See note 4 ante. The Definitive Map is accompanied by a definitive statement which defines the position or width of a right of way shown on the map, and any other limitations or conditions such as stiles etc.
} 
by surveying authorities charged with the upkeep of PROW maps and statements. ${ }^{143}$ Local authorities, ${ }^{144}$ in their individual capacity as Commons Registration Authority (CRA), are statutorily responsible for the maintenance of separate registers of common land ${ }^{145}$ and of town or village greens. ${ }^{146}$ Up to now this has been regulated, in the main, by CRA 1965 and regulations issued under it. ${ }^{147}$

Until recently, fulfilment of such statutory obligations has been inextricably linked to the presentation and description of the rights in paper form. For a number of reasons, however, pressure has begun to grow for a more accurate and interactive means of recording, updating and maintaining the existence of such rights. At the most basic level the depiction of geospatial information in digital format offers statutory authorities new means with which to visualise the discharge of their management responsibilities. Gone is the idea of a map as a single entity, defined by the area of land depicted on the square of paper upon which it is printed. Instead, this is replaced by an online searchable database containing information in geospatial and related text formats, capable of being stored and processed digitally.

Research conducted for the CAg by the GeoData Institute of Southampton University in 2005 (the 2005 Study), ${ }^{148}$ identified 35 CRAs already voluntarily holding various parts of their commons registers in digital format. This would be as 'back-up' to the 'definitive' paper copy. Forty-one declared they had no immediate plans to follow suit, but this was due more to their being too few areas of such land within their remits to make the process worthwhile. Other responses indicated "lack of time, finance, expertise, software or technical difficulties" than any principled antagonism to the concept of digitisation. Prior research in 2003, also carried out for the CAg by the GeoData Institute (the 2003 Study), ${ }^{149}$ found that paper-based definitive maps and statements of PROWs were frequently "out-of-date, expensive to maintain and ... increasingly fragile". Ad hoc pressure was also being exerted, at the time, by e-Government policy which was encouraging all parts of the public sector to embrace ICT. Its growing influence dictated the need to build services around citizens' choices. This required making government and its services more accessible and promoting social inclusion. Information should be used more effectively for both the public good and for the effectiveness and efficiency of

\footnotetext{
${ }^{143}$ S. 10 CROW Act 2000. The first review must be within 10 years of the date of issue of the map in conclusive form.

${ }^{144}$ The Commons Registration Act 1965 designates county councils (and unitary authorities exercising the functions of county councils), metropolitan borough councils and London borough councils as commons registration authorities.

${ }^{145}$ In England and Wales, a common (or common land) is defined as a piece of land over which other people - often neighbouring landowners - could exercise one of a number of traditional rights, such as allowing their cattle to graze upon it. The older texts use the word "common" to denote any such right, but more modern usage is to refer to particular rights of common, and to reserve the word "common" for the land over which the rights are exercised. By extension, the term "commons" has come to be applied to other resources to which a community has rights or access. Source: en.wikipedia.org/wiki/Common_land.

${ }^{146}$ Clause 15 Commons Bill 2005 [HL 173] indicates that registration of greens may be applied for where a "significant number of local inhabitants have indulged as of right in lawful sports and pastimes on the land for a period of at least 20 years; and they continue to do so at the time of the application”. See further note 18, ante.

${ }^{147}$ See further: www.defra.gov.uk/wildlife-countryside/issues/common/legislation/existing/reg-authorities.htm. The general regulations are The Commons Registration (General Regulations) (S.I. 1966 No. 1471).

${ }^{148}$ Registered Common Land and Town or Village Greens: Statutory Registers in electronic form, Report UC751/2 (GeoData Institute, University of Southampton, January 2005). See: www.defra.gov.uk/wildlife-countryside/ issues/ common/legislation/existing/digiregisters.htm.

${ }^{149}$ Review of the Technical and Legal issues around Electronic Definitive maps, UC620/1 (GeoData Institute, University of Southampton, June 2003).
} 
government. ${ }^{150}$ Links were also made by some public authorities between the availability of online geospatial information and the discharge of statutory obligations under s.19 of the Freedom of Information Act 2000. ${ }^{151}$ These required all public authorities to prepare 'publication schemes' setting out their information policies for the discharge of statutory 'freedom of information' obligations.

The first specific statutory move towards the transition from paper to digital format for the presentation of conclusive and definitive map data for the countryside came with CROW Act 2000. As previously stated, ${ }^{152}$ from 31 October 2005 section 2 of the Act came into effect granting a public recreational right to roam on open country and registered common land. ${ }^{153}$ Part 1 of the Act introduced a statutory scheme for the issue of conclusive paper maps of the relevant access land. A timetable for preparation of the definitive version of the maps was laid down which included a process that involved the issue of draft and provisional maps, followed by a period of consultation, appeal and resolution of all outstanding issues identified up to that point; and all to complete within a fixed time period, limited by the date when the access right was to come into effect. Section 9 indicated that a provisional map could be confirmed as 'conclusive' once this process was complete. In addition, without mandating that such action be followed through, section 11(3) of CROW Act 2000 opened the way for regulations to be brought forward to permit conclusive maps of access land to be "prepared, issued, published or made available for inspection in electronic form", subject to the proviso that such maps must be "capable of being reproduced" as hard copy. ${ }^{154}$

In assessing the Government's mapping aims up to this point it is quite clear that the overriding objective has been to deliver, within a reasonable timescale, conclusive status to paper maps of access land. The main concern has been to ensure that the public have a clear picture of the land, as set out on conventional maps, showing exactly where the right to roam exists. By making provision for periodic review of the maps, within 10 years of initial publication, subsequent amendments and corrections can be made without inhibiting their initial 'conclusive status'. It is also apparent that the Government has, at least, been tacitly prepared to embrace the principles eGovernment, by cautiously paving the way for a possible future transition of the conclusive status of those maps from paper to digital form. Conceivably, this might take place once a scheme can be prepared and when, politically, cost/benefit analysis directs that resources be found to manage and maintain the process. Commenting on this issue the 2003 Study remarked:

\footnotetext{
"The CROW Act 2000 allows for the development of a statutory map in digital form; it also allows for consultation on that map via the Internet, as part of a formal consultation process, and through regulations for the update and correction of minor errors and omissions. Each of these steps under CROW Act 2000 is a radical shift from the paper-based approach to production, consultation and dissemination of earlier statutory mapping. Whilst these may seem small steps, they mark a change in the long-held tradition of statutory maps in paper form, sacrosanct and perpetuating errors regardless of the quality and currency of the underlying base maps. The change in perception of definitive geographic information - as a spatial database - rather than a 'vellum' based map is an important step in modernising data management, in sharing information and in meeting e-government objectives.”155
}

\footnotetext{
${ }^{150}$ Modernising Government - e-government: A strategic framework for public services in the Information Age (Cabinet Office, April 2000) at: archive.cabinetoffice.gov.uk/e-envoy/resources-pdfs/\$file/Strategy.pdf. See further note 51 ante.

${ }^{151}$ Freedom of Information Act 2000, Ch.36.

152 See note 108 ante.

${ }^{153}$ See notes 13-14 ante. Under s.3CROW Act 2000 the definition of “open country” can be amended to include reference to coastal land of any description, including the foreshore and land adjacent to the foreshore.

${ }^{154}$ See notes $13-15 \& 187$ post.

155 Op cit note 149 ante, pp. 8-9.
} 


\subsection{Electronic registers of common land and greens}

Despite the statutory grant of public access rights to all registered common land and open country, and the requirement to publish conclusive maps of the land in question under CROW Act 2000 procedures, the Government quickly identified unfinished business with regard to future protection for commons. With a legislative record dating back to $1235^{156}$ and a long history of commons rights, ${ }^{157} 80 \%$ of the land still lay in private hands. ${ }^{158}$ Half of all commons could be found within the national parks and one third was further designated as either wholly or partially within AONBs. ${ }^{159}$ More than half was also designated as a SSSI. ${ }^{160}$ In addition, with "substantial areas of common land in lowland England and Wales valued for recreation, biodiversity, landscape and heritage”, the Government was keen to conserve the land for future generations to enjoy. Evidence presented to the Government suggested, for example, that either overgrazing or undergrazing of some of the land was taking place. Moreover, nearly half of all SSSIs within common land boundaries were found to be in ecologically poor condition. ${ }^{161}$ In the absence of a nationwide statutory management scheme to conserve such land, the combined effect of these trends was likely to result in "long term damage" to large areas of common land.

The main thrust of the Commons Bill 2005 is contained in two sets of measures. First, it makes provision for the agricultural management of commons through powers that permit the appointment of CAs. Within such associations commoners, landowners and other interested groups and individuals can engage in a management process of the land, based on majority decision making. ${ }^{162}$ This identifies a new role, beyond that of the CRA, whose statutory responsibility will continue to focus on the maintenance of the registers, as opposed to land management policy itself. ${ }^{163}$ Related measures are also proposed to protect commons from severance, ${ }^{164}$ letting or leasing of commons rights, ${ }^{165}$ as well as powers for national nature

\footnotetext{
156 The Commons Act 1285 (13 Edw 1 c.46). This Act is scheduled for repeal in the Commons Bill 2005 [HL 173 ].

${ }^{157}$ Examples of rights of common are: common pasture (right to pasture cattle, horses, sheep or other animals on the common land); common piscary (the right to fish); common turbary (the right to take sods of turf); estovers (the right to take sufficient wood for the commoner's house or agriculture). Clause 60 Commons Bill 2005 [HL 173] states that a "'right of common' includes a cattlegate or beastgate (by whatever name known) and a right of sole or several vesture of herbage or of sole or several pasture, but does not include a right held for a term of years or from year to year."

${ }_{158}$ See further: www.defra.gov.uk/wildlife-countryside/issues/common/.

${ }^{159}$ See further: www.defra.gov.uk/wildlife-countryside/issues/common/facts-figures.htm.

160 See notes 7 \& 27 ante.

${ }^{161}$ Full Regulatory Impact Assessment of Commons Bill - Summary June 2005 para 2.2 at:

www.defra.gov.uk/wildlife-countryside/issues/common/legislation/commons-bill/summary-ria.pdf. Production subsidies under the Common Agricultural Policy of the EU are blamed for encouraging over grazing and consequent damage to soil and vegetation in these areas.

${ }^{162}$ See Part 2 of the Commons Bill 2005 [HL 173] on management. See further note 20, ante. Clause 26 of the Bill states that the appropriate national authority (the Secretary of State, in relation to England; and the National Assembly of Wales, in relation to Wales) "may ... establish a body corporate [known as a commons association] to carry out functions conferred under this Part”.

163 The chief function of CRAs under the Commons Registration Act 1965 has been to administer the registration process. Today, this has been eclipsed by the duty to maintain the registers for public inspection, conduct searches from the public and conveyancers and deal with amendments, including registration of new greens or the removal of common land. See Commons Bill 2005 [HL 173] Part 1 for the revised statutory scheme governing the duties of CRAs and issues related to the conclusiveness and correction of the registers.

${ }^{164}$ See note 19, ante. Severance often meant that commons rights ended up in the hands of "farmers or graziers who do not live near the common, have no knowledge of the common itself, and may disrupt the livestock management practices there.” See: www.defra.gov.uk/wildlife-countryside/issues/common/legislation/commons-bill/.

165 See clauses 6-13 Commons Bill 2005 [HL 173].
} 
conservation bodies and National Parks Authorities to act against unauthorised activity on the land. ${ }^{166}$

Second, the Bill makes provision designed to improve the quality of the information contained in the registers of common land and of town and village greens and of the rights exercisable over such land. Currently the registers comprise a number of separate records, supported by official forms, such as those used for official register searches. ${ }^{167}$ In implementing these changes the whole of CRA 1965 is to be repealed. ${ }^{168}$ The Bill will require registers to be updated and maintained as a conclusive record ${ }^{169}$ of the land in question and of the rights that link to that land. CRAs will be placed under a statutory duty to amend their registers to correct errors ${ }^{170}$ or to reflect changes. The High Court will also have power to order such amendments if so required. ${ }^{171}$ In addition the Bill will clarify a number of outstanding registration issues concerning existing interpretation of the law under CRA $1965 .{ }^{172}$ Of particular significance for digital conversion is Clause 25 of the Bill. This establishes powers to enable regulations to be made either to require or permit the whole or part of a register to be kept in electronic form. The clause also sketches out, in somewhat broad terms, how the conversion process might be undertaken. Particular reference is made to arrangements for publicity about any proposed conversion, the production of a provisional electronic version for inspection and comment and, where necessary, to the holding of an inquiry into any issue arising from the conversion process itself.

Once the Bill becomes law it is unlikely that any swift decision will be taken by the Government to convert the registers into electronic form. A number of key issues first need to be resolved. For example, the Bill does not make it clear whether the process would be placed in the hands of CRAs or a national authority, such as the CAg, or both. A decision to centre the conversion process at local level would not necessarily mean that the transition process might not benefit from some form of national coordination and oversight, as occurred for example with the participation of CAg in the preparation of conclusive maps of access land under CROW Act 2000. This ultimately contributed to the success of the programme in establishing a consistent overall scheme that met the required deadlines. ${ }^{173}$

Such basic decisions must first be taken before any digital conversion scheme can be developed and implemented for the registers of common land and greens. It is important to note, however,

\footnotetext{
${ }^{166}$ Clause 46 Commons Bill 2005 [HL 173].

${ }^{167}$ Each registration would be divided into three sections with a description of the land, the rights of common attaching and known owners of the land. Entries concerning ownership were not held to be conclusive. Records also included non-statutory plans and forms and records of the dominant tenements to which the rights of common were attached.

${ }^{168}$ See section 1 of this paper, ante.

169 Clause 18 Commons Bill 2005 [HL 173].

${ }^{170}$ Such as land mistakenly left out from registration or removal of land wrongly registered. See Clause 19 Commons Bill 2005 [HL 173].

${ }^{171}$ Clause 19(7) Commons Bill 2005 [HL 173].

172 The most recent judgment was in Oxfordshire County Council v. Oxford City Council and another [2006] UKHL 25 (24 May 2006) the “Trap Grounds” case at: http://www.publications.parliament.uk/ pa/ld200506/ldjudgmt/ jd060524/oxf-1.htm. This ruled that, for the purpose of registration as a 'class c' green under s.22(1)(a) CRA1965, local inhabitants must continue to use the land for sports and pastimes for 20 years until the application for registration is made. Therefore, reversing the Court of Appeal, a landowner cannot end use of the land, as of right, following submission of an application for registration, thereby ensuring that registration was not possible, despite the requisite 20 year period of use having taken place. House of Lords amendments to Clause 15 of the Commons Bill 2005 [HL 173] will change the legal definition of a green and set out the qualifying circumstances in which the land may be newly registered. See: http://www.defra.gov.uk/wildlife-

countryside/issues/common/registration/pdf/commonsbill-letter.pdf.

${ }^{173}$ See note 106 ante.
} 
that under CROW Act 2000, the primary task was to deliver and publish conclusive maps of access land in paper form. The fact that OS Land-Line and subsequently OSMM were used to produce those maps ${ }^{174}$ did not mean that the legal and procedural issues connected with the online transfer of those conclusive maps from paper to digital form had been resolved, at least not then. According to the explanatory notes accompanying the Commons Bill 2005, the whole experience had:
"highlighted the difficulty of translating the information contained in old, relatively small scale Ordnance Survey register maps held by commons registration authorities, into a modern mapping database, and particularly in determining and locating accurate boundaries to registered land where the register maps are poorly drawn, indistinct or based on out-of-date mapping." 175

It was implicit within this statement that until the transition issue could be properly examined and an assessment made as to how this could be achieved, it would be unwise to act prematurely and invoke a conversion scheme that might ultimately prove to be defective. In its 2005 Study, presented to the CAg, the Geodata Institute commented thus:

\begin{abstract}
"The development of digital registers of common land and village greens at first seems a simple objective, but the distributed nature of the information, the variety of materials comprising the registers and supporting information and the varied transactions and authority approaches, makes this a more complex issue. The proposal to incorporate the power to generate registers in statutory electronic format, within the scope of new commons legislation, requires full evaluation of the data standards and requirements for maintaining a digital legal system. Maintaining standards and updating a digital register introduces a range of new issues for local authorities.”,176
\end{abstract}

The 2005 Study noted, however, that if a scheme could be established for the digital conversion of the registers, a range of benefits might be forthcoming. These were improved accuracy, better methods for incorporating amendments to the registers, the linking of registration data to other data of practical relevance to commons and greens management, and ease of data sharing. The process would also help to "ensure that worn out registers did not deteriorate further," while simplifying the "recording process, data retrieval and search and notification requirements." 177 However, before such gains could be made, the development of a robust scheme that incorporated appropriate standards and technical procedures was necessary. The lack of an advisory body to which CRAs could turn to for advice on digital conversion issues meant that a variety of approaches and systems had already been adopted by some authorities in developing their pilot programmes. The statutory registers contained not only the maps of the land in question but other register units as well. ${ }^{178}$ It was clear then that "national consistency" was required, as well as a better understanding of the legal weight and judicial consequences attaching to the conversion process itself. If this could be achieved there were also likely to be efficiency gains, reducing the number of repeated clerical activities involved in maintaining a textual register in paper format.

\footnotetext{
${ }^{174}$ News Release - Industry acclaim for Ordnance Survey at: www.ordnancesurvey.co.uk/oswebsite/media/ news/2005/ dec/IMawards.html. OSMM was not used initially as the basis for capture as it was not available at the start of the mapping programme. It was also found that areas of common land "rarely matched to MasterMap polygons”. Op cit note 148 ante, p. 44.

${ }^{175}$ Commons Bill 2005 [HL 49] Explanatory Notes at: www.publications.parliament.uk/pa/ld200506/ldbills/011/en/06011x-b.htm . See further note 17, ante.

${ }^{176}$ Op cit note 148 ante, p.1.

${ }^{177}$ Ibid Executive Summary and at p. 33

${ }^{178}$ Op cit note 148 ante, p. 46. The maps themselves are not a simple data set either, comprising provisional registers, insets and supplemental maps. See also note 167 ante.
} 
In addition to the above, technical problems also had to be overcome, mostly linked to the mapbased information or, less frequently, to the related text. For example, the mapping of commons "could not be simply related to the corresponding OSMM features and referencing polygons (parcels) of commons or greens to a TOID." This was because the boundaries to commons or of towns or village greens often related to boundaries no longer "present on the ground" and, therefore, not capable of presentation as parcels of land within OSMM. If redefinition of commons or greens' boundaries to OSMM features was to be achieved, new legislation would be required to link boundaries to physical features as occurred, for example, in the mapping of access land under section 4 CROW Act 2000. ${ }^{179}$ Other problems related to errors in the source materials of maps and registration documents, as well as issues of interpretation and transcription, where it was found that CRAs had not always followed the standards in the regulations of 1966-68. ${ }^{180}$ Mismatches between the register map and the textual register were also found as where, for example, a common might be shown as registered on the textual part of the register, but hatched as de-registered on the map, or vice versa. ${ }^{181}$

The 2005 Study concluded that existing ad hoc electronic data sets of statutory registers could not, because of their varied nature, form the basis for a consistent national conversion programme. However, there was scope for the process of adoption of maps of registered common land and open country, created under section 4 CROW Act 2000, to become the "graphic basis for establishing a definitive register in electronic form." 182 Among the advantages of the CROW Act 2000 scheme was the fact that the electronic data had been captured "against a recorded methodology and using standard digitisation procedures." 183 Also, the resulting digital maps had been captured on the most accurate topographic base map available and had been made subject to a validation process involving both CRAs and the general public.

Nevertheless, despite these positive statements, it was evident that even the CROW Act 2000 process left a number of outstanding issues to be resolved. For example, insofar as it was represented on the register, none of the land excepted from registration as common land was mapped. ${ }^{184}$ Not all land taken in exchange for other land given in its place had been captured and attributed either and there were errors in the textual registers, where gaps existed in the information held in digital form. Also recent changes, such as deregistered common land, might not yet have been mapped due to bureaucratic delay. Similarly, land removed as a result of a CROW Act 2000 appeal might still be shown to be registered common land when judicially that was no longer the case. ${ }^{185}$ However, the most significant disadvantage was the fact that, in addition to the above elements, town or village greens had not been captured either, although it was conceivable that these could be added to the same scanned register maps without too much difficulty. ${ }^{186}$ Despite these 'teething' problems, the CROW Act 2000 mapping experience was

\footnotetext{
${ }^{179}$ Ibid p.72. The DNF methods/models anticipate the fact that OSMM cannot provide all the atomic units required and so introduces the ability to introduce additional geometry to map those parts not shown on OSMM. These objects are also referenced and managed in the same way as OSMM objects, albeit within user systems.

${ }^{180}$ Op cit note 147 ante. See also note 14 ante and: Commons Registration (Objections and Maps) Regulations 1968 [S.I. 1968/989]; Commons Registration (General) (Amendment) Regulations 1968 [S.I. 1968/658]; Commons Registration (General) Regulations 1966 [S.I. 1966/1471]; Commons Registration (Time Limits) Order 1966 [S.I. 1966/1470]; Commons Registration (Publicity) Regulations 1966 [S.I. 1966/972]; Commons Registration (Exempted Land) Regulations 1965 [S.I. 1965/2001].

${ }^{181}$ Op cit note 148 ante, p. 78, i.e. void on the register but not hatched on the map.

182 Ibid pp. 82-84.

183 Ibid p. 82.

${ }^{184}$ Excepted land from Part 1 of the Act is set out in Schedule 1 CROW Act 2000 and includes parks, gardens, and land used for golf, horseracing, aerodrome, railways etc.

${ }^{185}$ Op cit note 148 ante, p. 83.

186 Ibid.
} 
found to offer much that could be taken and grafted into the broader digital conversion programme envisaged by section $11(3)$ of CROW Act $2000 .^{187}$

\subsection{Definitive electronic maps of public rights of way}

The outbreak of Foot and Mouth disease (FMD) in Great Britain in February 2001 brought the importance of public footpaths to the rural economy sharply into focus. The widespread closure of nearly all public footpaths during the first weekend of March 2001, ${ }^{188}$ 'dubbed' by the media as the "closure of the countryside," was later found to have had a greater economic impact than it did upon disease control. The subsequent 'Lessons to be Learned Inquiry' ${ }^{189}$ had difficulty establishing the audit trail that led Ministers to take the decision to close PROWs beyond the infected areas, although it did find that the National Farmer's Union supported widespread closure. The National Trust described it as "the most costly decision of the entire outbreak", although the Trust itself had also initially supported the closure. ${ }^{190}$

The Pre-Budget Report $2001^{191}$ estimated that the overall impact of the FMD epidemic on UK Gross Domestic Product was approximately $£ 2$ billion. Other interpretations put the cost of the outbreak at $£ 8$ billion or more, with at least $£ 3$ billion of direct costs to the public sector. ${ }^{192}$ In Devon alone, with 4,900 km of PROWs in the County, figures (subsequently revised down) suggested that tourism losses amounted to $£ 107$ million at a cost of up to 3,300 jobs. ${ }^{193}$ From late March 2001 the Government encouraged local authorities to re-open footpaths, but progress was slow. By mid May 2001 just one quarter had been re-opened and only from February 2002 could it reasonably be said that the process of reversing the closures was all but complete. ${ }^{194}$

In their submission to the 'Lessons to be Learned Inquiry' the Ramblers Association pointed out that walking was the "most popular sporting activity in the UK" and that this form of recreation had remained top in all four of the General Household Surveys conducted over the past 20 years. ${ }^{195}$ The FMD experience had brought the issue of "revitalisation" of the countryside up the political agenda together with the need to welcome back the public to rural areas. But this required more information on access to footpaths, national trails and other attractions. Local authorities could, for example, "identify footpaths and trails that generate sufficient income within local economies and draw up plans for their improvement.”"196 The publication, in July

\footnotetext{
${ }^{187}$ See notes $13-15$ \& 154 ante.

188 The Foot-and-Mouth Disease (Amendment) (England) (No. 2) Order 2001 (S.I. 2001 No. 680 at: www.opsi.gov.uk/si/si2001/20010680.htm.

${ }^{189}$ Foot and Mouth Disease 2001: Lessons to be Learned Inquiry Report HC 888 (Stationery Office, London, July 2002) at: archive.cabinetoffice.gov.uk/fmd/fmd_report/report/.

${ }^{190}$ Ibid p. 63.

${ }^{191}$ Pre-Budget Report CM 5318 (HM Treasury, November 2001).

192 Campbell and Lee, The Foot and Mouth Outbreak 2001: Lessons not yet learned at: www.fmd.brass.cf.ac.uk/lessonsnotlearnedDCBL.pdf. The National Audit Office suggested a figure exceeding £8 billion. Source: The 2001 Outbreak of Foot and Mouth (Stationery Office, London, June 2002) at: www.nao.org.uk/publications/nao_reports/01-02/0102939.pdf.

${ }^{193}$ Crisis and Opportunity - The Report - Voices from the written submissions to the Devon Inquiry 3 - M. Chorlton, Devon County Council at: www.devon.gov.uk/fminquiry/finalreport/voices/writtenvoices3.html.

194 The 2001 Outbreak of Foot and Mouth (Stationery Office, London, June 2002), p. 35.

${ }^{195}$ Foot and Mouth Disease: Lessons to be Learned Inquiry Ramblers' Association submission (14 March 2002) at: www.ramblers.org.uk/info/publications/PDF/lessonslearned.pdf. It reported that 26 million visits to the countryside in 1998 generated spending of $£ 2.7$ billion. See further: Christie and Matthews, The Economic and social value of walking in England (September 2003) at: www.ramblers.org.uk/campaigns/EconVal.pdf.

${ }^{196}$ Report of the Rural Task Force - Tackling the impact of foot-and-mouth disease on the rural economy (Department for Environment, Food and Rural Affairs, October 2001) para 8.30.
} 
2004, of the Government's Rural Strategy ${ }^{197}$ made explicit reference to the "difficult experience" of rural areas since FMD and the need to act upon the lessons learned. This policy analysis, in turn, has fed into the legislative programme in which NERC Act 2006 now implements key aspects of the rural strategy agenda.

In relation to PROWs, however, NERC Act 2006 makes only minor changes to the law. ${ }^{198}$ The CROW Act 2000, which of course pre-dated the FMD outbreak, in fact makes more significant improvements to the management of rights of way. This imposes a statutory duty on local authorities to review their rights of way networks and identify improvements that can be made to meet the Government's aim of "better provision for walkers, cyclists, equestrians and people with mobility problems." ${ }^{\text {"199 }}$ Within that programme, however, DEFRA has not yet ventured into discussion with local authorities, in their statutory capacity as surveying authorities, ${ }^{200}$ as to improvements that could be made to the maintenance of the definitive map and statement of PROWs within their charge.

The law governing proof of existence of a PROW lies in the maintenance of the legal record of the right of way within the definitive map and accompanying statement. The latter provides information as to the position or width of the path as well as details of any conditions or limitations attached to the right. The conventional paper record so assembled provides conclusive evidence, under present rules, as to the existence and extent of the right. There are estimated to be approximately 118,750 miles of PROWs in England recorded on definitive maps. ${ }^{201}$ Of these more than $75 \%$ are public footpaths, ${ }^{202}$ with the remainder comprising either public bridleways, ${ }^{203}$ restricted byways ${ }^{204}$ or byways open to all traffic. ${ }^{205}$

The statutory framework for definitive maps and statements of PROWs was originally set out in NPACA 1949. Later on their statutory regulation was replaced by WCA 1981 sections 53-57. Section 53 WCA 1981 requires that the definitive map be kept under "continuous review" by the surveying authority, within a process of modification and reclassification orders that detail changes that have occurred. Periodically, re-publication of the definitive map must also take place. Copies of the definitive map and statement together with copies of all modification and reclassification orders must be kept by the surveying authority. These must be available at reasonable hours for public scrutiny. Regulations, introduced in $1993,{ }^{206}$ prescribe the form such orders should take, as well as instructions that the scale of definitive maps should not be less than

\footnotetext{
${ }^{197}$ Op cit note 22 ante.

198 See notes 22-27 ante.

199 Op cit notes 13-17 ante. See also Rights of Way Improvement Plans - Statutory Guidance to Local Highway Authorities in England (Department of the Environment, Food and Rural Affairs, November 2002) para 1.1.7 at: www.defra.gov.uk/wildlife-countryside/cl/rowip/rowip.pdf.

${ }^{200}$ County councils, metropolitan district councils or London borough councils whose area includes the PROWs in question.

${ }^{201}$ Managing Public Access - A Guide for Land Managers (The Countryside Agency, March 2005) p. 16.

${ }^{202}$ Rights of way on foot comprising 91,000 miles of public footpaths in England.

${ }^{203}$ Rights of way on foot or on a horse. Bicyclists can also use these paths but must give way to other users. Some rights to drive cattle or other animals may exist. There are 20,100 miles of public bridleways.

${ }^{204}$ A new category of right under ss. 47-52 CROW Act 2000 granting public access on foot, horseback, cycle or horse-drawn vehicle. Includes all the above plus other non-mechanically propelled vehicles (such a horse drawn carriage). For more detailed legal definitions of PROWs see:

www.dft.gov.uk/stellent/groups/dft_localtrans/documents/page/dft_localtrans_028 709.hcsp.

${ }^{205}$ Includes all of the above, plus use of wheeled vehicles of all kinds including mechanically propelled ones. They differ from public roads in that they are likely to be used for similar purposes as footpaths and bridleways. There are 2,300 miles of such byways.

${ }^{206}$ The Wildlife and Countryside (Definitive Maps and Statements) Regulations (S.I. 1993 No. 12) at: www.opsi.gov.uk/si/si1993/Uksi_19930012_en_1.htm.
} 
1:25,000. Surveying authorities wishing to adopt a larger scale could do so with the addition of an inset map for that purpose. ${ }^{207}$ A survey of surveying authorities, reported in the 2003 Study, ${ }^{208}$ showed that several had begun to use the 1:5,000 map scale on the basis that the prescribed smaller scale map often failed to provide sufficient detail. ${ }^{209}$

At issue now is the speed and extent to which the whole process might be susceptible to digitisation and what type of scheme might be introduced to facilitate conversion of such definitive maps and statements into digital form that would satisfy legal requirements. In contrast with the mapping of access land under CROW Act 2000, where a process for the publication of conclusive maps was established within that legislation, ${ }^{210}$ a robust scheme commencing with NPACA 1949 for the maintenance of conventional definitive maps and changes to PROWs records has operated for more than 50 years. ${ }^{211}$ Although such statutory arrangements might usefully be drawn upon in developing a process for digital conversion, a significant difficulty for some areas of the country is the variable quality of the records. The 2003 Study found evidence of "large backlogs of records and modification orders", where surveying authorities had simply failed to consolidate changes and where the record was "confused at best." Yet, despite these difficulties, there was strong support among the latter for a decisive move towards digitisation, with some authorities already using digital working copies of their statutory paper maps. Durham County Council is a case in point, with a web page dedicated to advising the public about its definitive map and how rights may be exercised by the public in relation to it. It further describes the authority's ongoing digitisation project which commenced in 2003. This will convert its current paper-based definitive maps into digital form with the aim of producing a new map by 2007-08. The County Council commented thus:

\begin{abstract}
"Once up and running, it is hoped the benefits of having this information held digitally will significantly improve the use, planning and management of the PROW network and allow for alterations to the network to be displayed as soon as they occur to anyone with access to the Internet.... Digitisation is being undertaken on a parish-by-parish basis. A process has been adopted, checking various editions of the definitive map, old editions of Ordnance Survey maps, aerial photography and the description of where PROWs are recorded as going, from the definitive statements. It also involves taking into account any modification orders that have taken place, including diversions, creations and stopping up. Once fully digitised it is hoped that, at some point in the future, an up-to-date 'real time' version of PROWs in County Durham will be made available for viewing to members of the public from the DCC website."212
\end{abstract}

If similar projects are to be developed elsewhere, rules and guidelines of this sort will be required. These must ensure that a multiplicity of digital conversion schemes do not emerge that may conflict with any future government proposals or challenge the high standards of record keeping required for judicial acceptance of definitive status in digital form. Many of the authorities that replied to the 2003 Study questionnaire in fact indicated that a national standard

\footnotetext{
${ }^{207}$ Maps generated under NPACA 1949 were typically drawn at the 1:10.560 scale of 6 inches to the mile, being the contemporary map scale at that time.

${ }^{208}$ Op cit note 149 ante.

${ }^{209} 60 \%$ of authorities responding to the survey would welcome a larger standard scale. Some would prefer to stay at 1:10,000 while others favoured 1:2,500. There was considerable interest in 1:5000 as a 'new' standard scale.

${ }^{210}$ See notes 14,106 and 173 et seq, ante.

${ }^{211}$ The scheme is well set out in a guide by the Countryside Agency entitled: A guide to Definitive maps and changes to public rights of way (The Countryside Agency, November 2003) at: www.countryside.gov.uk/Images/CA\%20142_tcm2-14193.pdf.

212 The Durham County Council definitive map web page can be found at: www.durham.gov.uk/durhamcc/usp.nsf/pws/Public+Paths+-+The+Definitive+Map.
} 
would be welcome, provided it was "endorsed, properly supported and fully resourced by government and local authorities." 213

Technical issues will also need to be addressed. Given its national coverage, the strong assumption must be that OSMM will form the base map for any future national conversion scheme. The Topography Layer of OSMM depicts roads, tracks and paths both made and unmade. The edges or centre alignments of tracks and paths are shown and a five year project is now underway to introduce textual descriptions. These might be descriptive, such as "cliff, scrub or standard gauge track"; or distinctive, such as "River Thames or New Forest". ${ }^{214}$ However, rights of way, as such, are not identified within the Topography Layer. Such digital representation of a road, track or path is, in any case, no evidence of the existence of such rights, as statutory recognition is still firmly fixed upon the definitive map in paper form. Because of this, no detailed discussions have yet taken place between surveying authorities and OS regarding updates to the definitive map, although a regular dialogue does exist to support small scale mapping activity. Consequently, because of the apparent inertia, surveying authorities have often continued to maintain definitive maps that fail to account for landscape changes in the representation of PROWs.

It is likely, therefore, that a "sealed and unique copy of the data layer" within OSMM will be required for a digital version of the definitive map to be achieved nationally. ${ }^{215}$ Otherwise, the impact of path changes upon OSMM's topographic identifiers might require regular updating within the main database and this may not be something that OS would wish to resource. Moreover, if the 1:5,000 scale for the definitive map is to be adopted nationally, its implementation may need to be negotiated with OS via a 'service level' agreement. ${ }^{216}$ In practice, this is unlikely to present a problem, as it is preferable to capture the map data at as high a resolution as possible. Other related issues concern the archiving of modifications to the definitive map and the audit trail leading to those changes. Corrections to the base map itself brought about by the OS PAI programme ${ }^{217}$ must also be accommodated in smoothing out alignment errors from data sets captured against older maps.

The 2003 Study concluded that the operation of PROW management and enforcement was best left to local authorities to continue undertaking. This would appear to be the best course of action as local knowledge and expertise, linked to the economic and social benefits of maintaining local routes, offers an attractive incentive for conversion schemes to be planned and implemented. However, the 2003 Study also identified "clear advantages to the centralisation of data capture for data standardisation and compatibility." 218 Settlement of standards was the "greatest challenge" to the achievement of a definitive national PROW database. Impetus might be gained, however, through adoption of recording protocols such as Part 4 BS7666 (updated in 2006) for spatial georeferencing, ${ }^{219}$ although it was apparent that some surveying authorities had failed to

\footnotetext{
${ }^{213}$ Op cit note 149 ante, p.34.

${ }^{214}$ Ordnance Survey Glossary - Mapping terminology and acronyms (2006) at: www.ordnancesurvey.co.uk/oswebsite/aboutus/reports/misc/glossary.html.

${ }^{215}$ Op cit note 149 ante, p. 60.

${ }^{216}$ OS will also attribute an object with an accuracy indicator to help the user understand whether it is fit for purpose.

${ }^{217}$ See notes 81 and 136 ante.

${ }^{218}$ Op cit note 149 ante, p. 68.

${ }^{219}$ BS7666: Part 4: 1996 Spatial data-sets for geographical referencing. Specification of a data-set for recording public rights of way IST/36 BSI, London 24 pp at: www.geog.soton.ac.uk/research/agsig/resources.htm. This became redundant at the end of April 2006 when BS7666:2006 was published. Part 4 becomes obsolete and any PROW will move to the new Part 1.
} 
adopt this standard for rights of way data in schemes they had already started. National coordination of the conversion process might further benefit from advice on records management and archiving, such as that offered by the Public Record Office. ${ }^{220}$ The 2003 Study concluded that "without careful planning and adherence to archival procedures,"221 there was a risk of loss of access to the record. There was "enough experience of lost or poorly maintained paper data sets to provide caution when moving towards the legal deposit in electronic form."222

In contrast with the powers available under CROW Act 2000, that permit by regulation the formulation of arrangements for the introduction of conclusive maps of access land in electronic form, ${ }^{223}$ and also of the Commons Bill 2005 for electronic registers of common land and greens, ${ }^{224}$ no such specific powers have been promulgated, either through WCA 1981 or any subsequent legislation, to authorise electronic definitive maps and statements of PROWs. The question arises then, whether the Government could sanction a digital conversion scheme for PROW maps without further need to resort to primary legislation in order to amend existing law? A possible positive response lies in the power to produce regulations under sections 8-9 of ECA $2000 .^{225}$ The broad purpose of this Act is to facilitate electronic commerce through development of cryptography support services and legal recognition of electronic signatures. By section 8 ECA 2000, however, its eGovernment credentials are exposed since it also defines powers for undertaking conventional communications, document management and records storage electronically:

“8 (1) the appropriate Minister may by order made by statutory instrument modify the provisions of any enactment ...in such manner as he may think fit for the purpose of authorising or facilitating the use of electronic communications or electronic storage (instead of other forms of communication or storage) for any purpose mentioned in subsection (2).

(2) Those purposes are -

(a) the doing of anything which under any such provisions is required to be or may be done or evidenced in writing or otherwise using a document, notice or instrument;

(b)-(d) ...

(e) the keeping, maintenance or preservation, for the purposes of or in pursuance of any such provisions, of any account, record, notice, instrument or other document.

(f)-(m)”

Subsection 8(3) provides, in terms, that the appropriate Minister should not make such an order unless he considers that the availability of the electronic version of the record is at least as satisfactory, when compared, as the arrangements for record keeping implicit in the paper version. ${ }^{226}$ Section 9 ECA 2000 confirms that the "appropriate Minister" will be the Secretary of

\footnotetext{
${ }^{220}$ Management, appraisal and preservation of electronic records Vol. 1 Principles and Vol II Procedures $2^{\text {nd }}$ Edition (Public Record Office, 1999) at: www.nationalarchives.gov.uk/electronicrecords/advice/guidelines.htm. ${ }^{221}$ Op cit note 149 ante, p. 55.

222 Ibid.

${ }^{223}$ See notes $13-17$ and 152-155 ante.

${ }^{224}$ Op cit notes 18 and 163 ante.

225 The Act is consistent with, and seeks to implement, certain provisions of the EU Electronic Signatures Directive (1999/03/EC) adopted on 13 December 1999 (OJ L 13/12, 19.1.2000).

${ }^{226}$ Examples of regulations issued under ss.8-9 ECA 2000 include, inter alia,: The Prescription Only Medicines (Human Use) (Electronic Communications) Order 2001 (S.I. 2001 No. 2889) at: www.opsi.gov.uk/si/si2001/200128 89.htm; The Building Societies Act 1986 (Electronic Communications) Order (2003 S.I. 2003 No. 404) at: www.opsi.gov.uk/si/si 2003/20030404.htm; and The Companies Act 1985 (Electronic Communications) Order (S.I. 2000 No.3373) at: www.opsi.gov.uk/si/si2000/20003373.htm.
} 
State for the department with responsibility for the matter concerned. ${ }^{227}$ Section 8(4) ECA 2000 defines the scope of provisions that may appear in the Order including, inter alia, the form to be taken by any electronic communication or storage; conditions subject to which use may be authorised; the use of intermediaries to establish authenticity or integrity of any data; access fees and charges; liability for false statements; and records that may be required and kept in connection with such electronic communication or storage.

It would seem, therefore, that a fully operable statutory scheme already exists to establish a framework for the grant of statutory permission for electronic definitive maps and statements of PROWs. The real question now for Ministers to determine is whether they perceive that there are gains to be made in commencing a PROW digital conversion scheme at this time. Improvements to arrangements currently operating among surveying authorities would certainly need to be observed. It may be that recent experience of departmental problems in the handling of foot and mouth disease may encourage the Government to invest resources in a national PROW database. This could be updated regularly by data submitted by surveying authorities to OS in the maintenance of the OSMM record, assuming that the latter is adopted as the specified information system. It is likely that, once the technical specification for the conversion process can be agreed upon and specified in the Order, attention will be drawn to the extent of any transition period that might be necessary to deal with any problems associated with defective records and poorly maintained maps and statements. A timetable for resolution of these matters would need to be factored into any proposed scheme, and a process and guidance for records audit settled upon to ensure that the representation of PROWs within the Topography Layer of OSMM is accepted in court as admissible and incontrovertible evidence of the nature and existence of such rights.

Given the size of the task, it may suit surveying authorities, OS and the Government if a two stage timetable for the conversion programme was pursued. The initial date could define the deadline for completion and publication of the first edition of the electronic definitive map and statement. This could be followed by a second and later date for eradication of all errors to that data. The deadline for inclusion of previously unrecorded PROWs on the definitive map set by sections 53-56 CROW Act 2000 is 1 January $2026 .{ }^{228}$ This might similarly be adopted as a convenient 'second period' deadline for correction of all remaining errors arising from the digital conversion process itself. The consequent uncertainty during the transitional phase affecting all parties connected with the process should not, however, be under-estimated. On the other hand, the definitive map will in any case continue to remain subject to amendment up to that date, to deal with identification of 'lost ways'. There is no obvious reason then why this time period could not also extend to digital conversion of the definitive map. No doubt regulations could specify suitable arrangements for public consultation and appeal in respect of the process, based on existing statutory arrangements within WCA 1981 suitably modified to conform to the proposed timetable.

\section{Conclusion}

\footnotetext{
${ }^{227}$ This is likely to be Jim Knight MP, Minister for Rural Affairs with responsibility for access, rights of way and common land. See: www.defra.gov.uk/corporate/ministers/knight.htm. Consultation would probably also take place with the Minister of Communities and Local Government at ODPM and the Parliamentary Secretary at the Cabinet Office with responsibility for eGovernment.

${ }^{228}$ See notes 16-17 ante.
} 
This paper has examined the current state of development in the integration of digital geospatial techniques into UK mapping of designated land and the marine environment. It has shown that while much has been achieved the process is under-resourced and in need of more investment and better quality management. If this task is to be accomplished within the framework of eGovernment 'transformation' policy, then a national geographic information strategy needs to be implemented. Much therefore rests on the shoulders of the GI Panel in advising Ministers on the priorities for digitisation of geospatial information and where use of such tools can best contribute to land use planning and broader policy development. ${ }^{229}$ Furthermore, commonality of format in the presentation of geospatial information will become more useful and necessary as the increasing weight of EC directives is felt upon Member States, imposing an ever expanding range of domestic reporting obligations.

In assessing the current level of development in digital geospatial resources, the strength of the contribution of OS must be noted. OS has been ever present and has developed national mapping from the days before the national grid, when paper maps dominated, to the present day where OSMM can now deliver an 'intelligent' digital resource, presenting topographic features as real world objects and able to support a wide range of customer applications that utilise geographic information. If this template is carefully managed and permitted to evolve within the framework of EU policy, it is likely to become an essential component in the utilisation of digital geospatial resources throughout both the public and private sectors. But this technology has the potential to offer something beyond mere improvement in the presentation and visualisation of geospatial information. Its capacity to store and process the latter and to present it in a variety of forms is just one of the many additional features that the technology can offer. Moreover, the potential for added value arising from greater precision in the processing of such data offers scope for fulfilment of a wide range of additional user needs. It this way it can enable policy makers and those responsible for designated land and the marine environment to operate with greater efficiency and with a level of creativity and perception that mere access to and use of hard copy documentation and information could never facilitate.

Whilst OS must continue to enhance and develop its core data sets, its customer base comprising government departments, agencies, local authorities and range of non governmental organisations, must make their contribution too. They must build the specific applications to use in conjunction with the latter that will enhance their own performance and capabilities. Despite the different interests involved, the means to share geospatial information among a wide range of potential recipients will facilitate cooperation and understanding among bodies that either share responsibility or exercise a range of overlapping statutory duties over wide areas of land and marine space. Beyond that is the additional challenge facing both national and local government to develop schemes for digital conversion of its mapping portfolios. Given the long term benefits of digitisation for both governing authorities and the general public the process is inexorable, the only issue being how and when government should act and how best to manage and resource the transition.

Having said that, the development of digital geospatial applications remains firmly reliant upon political judgement as to when and how the technology should be used. Such tools provide policymakers with sharper means to develop a better understanding of what is happening to geographic space and from this models can be developed to aid decisions on policy. The contribution of ICT to this process is found in the support it gives the decision maker in marshalling data, testing hypotheses and delivering the ability to consult the data in a manner

\footnotetext{
${ }^{229}$ See notes $48-49$ and 125 ante.
} 
that would not have been so readily accomplished in the offline world. The effective presentation of what would otherwise be a complex web of data is, therefore, a small but important step in the process of decision making that governs the management, use and regulation of designated land.

In conclusion, it is clear that the deployment of digital geospatial techniques to land use planning and the marine environment remains in its early stages. There is still a great deal of work to be done in developing the technology of this emerging field. Immediate challenges can be found in the exploitation of three dimensional mapping and in the integration of aerial photography and satellite imagery into data sets of the kind rudimentarily incorporated for some parts of the world by 'Google Earth' ${ }^{230}$ and Microsoft's 'Virtual Earth'. ${ }^{231}$ The Government needs to support digitisation programmes where the national interest dictates and to continue to work with OS and other organisations in the development of mapping services and digital geospatial applications. Along with other governments it also needs to sort out its information policy on issues such as access, pricing, competition and private sector participation in creation of value-added products. Increasing public awareness and support for measures to both protect and enhance the environment must also not be ignored. If it can be shown that there is a definite connection between utilisation of the new mapping technologies and these particular goals, then politicians would be wise to adopt a strategic approach and find the necessary resources to support them. ${ }^{232}$ In doing so governments will no doubt be guided by the ambitions of eGovernment transformation policy, designed to improve services and ensure that public administration plays a full part in building the information society and exploiting the ICT revolution that accompanies it. $^{233}$

\section{ACRONYMNS used in this paper}

$\begin{array}{ll}\text { AONB } & \text { Area of Outstanding Natural Beauty } \\ \text { BGS } & \text { British Geological Survey } \\ \text { BVC } & \text { Black \& Veatch Consulting Information Solutions Group } \\ \text { CAg } & \text { Countryside Agency } \\ \text { CAs } & \text { Commons Associations } \\ \text { CIS } & \text { Countryside Information System } \\ \text { CRA } & \text { Commons Registration Authorities } \\ \text { CRA 1965 } & \text { Commons Registration Act } 1965 \text { c.64 } \\ \text { CROW Act } 2000 & \text { Countryside and Rights of Way Act } 2000 \text { c.37 } \\ \text { DAMS } & \text { Desktop Access Management System } \\ \text { DCLG } & \text { Department for Communities and Local Government } \\ \text { DEFRA } & \text { Department for Environment Food and Rural Affairs } \\ \text { DOE } & \text { Department of the Environment } \\ \text { DNF } & \text { Digital National Framework } \\ \text { DXF } & \text { Data Exchange Format }\end{array}$

\footnotetext{
${ }^{230}$ Google Earth is a 3D graphics application enabling the viewing of aerial photography and satellite images to show views of the Earth from above in great detail. See: http://earth.google.com/.

${ }^{231}$ The service is intended to offer satellite images with street overlays and the ability to add local layers. See: http://local.live.com/ and Windows Live Local which "combines mapping and local search to put the answers to ...search questions in a geographical context. To do this, Windows Live Local combines MSN Search with the latest in mapping to create a new Web application built on Microsoft technology.” Source: http://local.live.com/.

${ }^{232}$ I am grateful to this paper's reviewers for making this point.

${ }^{233}$ Modernising government - e.government: A strategic framework for public services in the Information Age (Cabinet Office, April 2000). See further note 51 ante.
} 


\begin{tabular}{|c|c|}
\hline ECA 2000 & Electronic Communications Act 2000 c.7 \\
\hline ESA & Environmentally Sensitive Area \\
\hline FMD & Foot and Mouth Disease \\
\hline GI Panel & Geographic Information Panel \\
\hline GIS & Geographic Information Systems \\
\hline GPS & Global Positional System \\
\hline ICZMap & Integrated Coastal Zone Mapping \\
\hline ITN & Integrated Transport Network Layer \\
\hline LCM2000 & Land Cover Map 2000 \\
\hline MAGIC & Multi-Agency Geographic Information for the Countryside \\
\hline MNRs & Marine Nature Reserves \\
\hline MSA & Mapping Services Agreement \\
\hline MSP & Marine Spatial Planning \\
\hline NERC & Natural Environment Research Council \\
\hline NERC Act 2006 & Natural Environment and Rural Communities Act 2006 c.16 \\
\hline NLUD & National Land Use Database \\
\hline NNR & National Nature Reserves \\
\hline NPA & National Parks Authority \\
\hline NPACA 1949 & National Parks and Access to the Countryside Act 1949 c.97 \\
\hline NGD & National Geographic Database \\
\hline NTF & National Transfer Format \\
\hline ODPM & Office of the Deputy Prime Minister \\
\hline OGC & Open GIS Consortium \\
\hline OS & Ordnance Survey \\
\hline OSMM & OS MasterMap \\
\hline OSPAR & $\begin{array}{l}\text { Convention for the Protection of the Marine Environment of the North } \\
\text { East Atlantic }\end{array}$ \\
\hline PAI & OS Positional Accuracy Improvement Programme \\
\hline PROWs & Public rights of way \\
\hline SACs & Special Areas of Conservation \\
\hline SPAs & Special Protection Areas \\
\hline SSL & SeaZone Solutions Ltd \\
\hline SSSIs & Sites of Special Scientific Interest \\
\hline TOID & Topographic Identifier \\
\hline UKHO & UK Hydrographic Office \\
\hline WCA 1981 & Wildlife and Access to the Countryside Act 1981 c.6 \\
\hline WLAG & Wildlife and Access Advisory Group \\
\hline
\end{tabular}

